\title{
To What Extent Do the Investment Programs in the Infrastructure Sector Comply with the Determinants of National Competitive Advantage?
}

\author{
K. M. Anwarul Islam ${ }^{1}$ \\ Orobah Ali Barghouthi ${ }^{2}$
}

\begin{abstract}
${ }^{1}$ Department of Business Administration, The Millennium University, Dhaka, Bangladesh
${ }^{2}$ Faculty of Business and Economics, Department of Banking \& Finance, Alquds University, Abu Dis, Palestine. Correspondence: Faculty of Business and Economics, Department of Banking \& Finance, Alquds University,Abu Dis, Palestine, E-mail: obargothi@ hotmail.com
\end{abstract}

Received: November 20, $2017 \quad$ Accepted: November 25, $2017 \quad$ Online Published: January 5, 2018

\begin{abstract}
The paper has examined what needed has to spend on infrastructure projects that would support the private sector, create real work opportunities, and improve productivity. We're also not spending evenly on sectors that could contribute to a sustainable economic stimulus, make our products more competitive, and attract investment capital. The PIF has in fact taken on this role. Even though it cannot cover everything, it is working in a number of sectors, including communications, energy, and housing - all sectors that spur growth.The fiscal situation, as any observer of Palestine's economy knows, remains unstable. Obviously expenditure goes primarily to salaries and current expenditures as a result of the extraordinary circumstances. And obviously this situation can only deepen Palestine's dependence on donors.
\end{abstract}

Keywords: SMEs, PIF, Infrastructure Sector.

\section{Introduction}

The researcher, with the data provided in the 2011 Palestine Investment Fund Annual Report analyzed the different determinants of national competitive advantage and interpreted through the use of prior concepts and expert views from key personalities.

\subsection{Wataniya Mobile \\ 1.1.1 Demand Conditions}

There is an increase in the number of subsidiaries. This lead to an increase in revenue amounting to approximately US\$ 5.9M.

\subsubsection{Supporting and Related Industry}

Provided high quality advanced telecom services through the use of modern network and building its stations in compliance with environment and regulatory standards and criteria. 


\subsubsection{Firm Strategy, Structure and Rivalry}

An increase in revenue approximately $96 \%$ derived from US\$ $12.7 /$ subscriber (US\$ 5.9M). There is also an increase in operational income which is seen as a $118 \%$ increase.

\subsection{Palestine Electricity Company}

\subsubsection{Factor Conditions}

Employs both technical and non-technical workforce. The number of employees is at 166.

\subsubsection{Supporting and Related Industry}

Observes an increase in environmental standards in tis operations and complies with the related World Bank standards and Palestinian environmental standards. An increase in income by US\$ 1.67M from 2010.

\subsubsection{Firm Strategy, Structure and Rivalry}

The company is composed of administrative staff, engineers and technicians.

\subsection{West Bank Power Generation Plant}

\subsubsection{Demand Conditions}

Initial capital of US\$2M. It continually meets the growing demand. This reduced the reliance on imported power from Israel.

\subsubsection{Firm Strategy, Structure and Rivalry}

The challenge for the company now is to identify an appropriate site that is to secure gas supply for the project.

\subsection{Gaza Gas Project}

\subsubsection{Factor Conditions}

There is a need to excavate for natural gas and the Gaza Coast. Excavation and exploration

\subsubsection{Demand Conditions}

Provide natural gas reserves available for domestic power generation.

\subsubsection{Firm Strategy, Structure and Rivalry}

Challenges that face the project includes a legal battle where export of natural gas to international market where there is a de facto control on the part of Israel. There is also a refusal to implement required measure to extend a pipeline in Egypt, a pre requisite to liquefying the gas and exporting it to international markets. There is also a refusal to provide the necessary clearances for developers. Even the negotiation for exportation of gas to Israel failed.

In the last few years PIF has launched a number of landmark projects including: US\$700 million mobile company, Wataniya mobile, in partnership with Qatari Qtel; US\$1.5 billion affordable housing program to develop 30,000 affordable housing units over the coming 5 years; US $\$ 400$ million commercial real estate development in downtown Ramallah ("Ersal Center"), in partnership with the Land Holding, KSA (a member of AlRajhi Investment Group); US\$500 million mortgage finance program in partnership with US based Overseas Private Investment Corporation and the International Financial Corporation, amongst others. PIF works in partnership with international, regional and local partners, based on values of transparency, accountability, commitment and in line with its corporate social responsibility and sustainability objectives. PIF has a strong reputation across global markets as a trusted and responsible investment partner.

In his expert opinion, Mustafa believes that to large extent investments of the last two years in the communications, financial, and real estate sectors has been observed. Take for example the communications sector. From 1997 Palestine had only one cellular provider, making this sector one of the few remaining markets where there was a monopoly. And despite the Authority's frequent mention of the need to open this sector to competition, which was echoed by donor reports, and the actual establishment of independent regulatory bodies in the field, there had been no discussions with Israel concerning frequencies-in fact, Israel refused to talk to 
the Authority about dedicating additional frequencies for communications networks from 2003 to 2007 . A highly reputable firm with extensive regional experience, Wataniya International of Kuwait-currently majority-controlled by the Qatari telecommunications giant Qtel-took up the challenge and partnered with PIF to create Wataniya Mobile. Despite the risks, the unavailability of frequencies, and huge obstacles such as Israel's ban on allowing equipment to enter the territories, the Authority received \$354 million for the license plus 7 percent of all Wataniya Mobile revenue. This was a great economic achievement as well as having nationalist implications. PIF brought in a foreign investor, and liberated some frequencies. This is what it means to control our natural resources: today it is frequencies, tomorrow it will be water, and next, land. The financial sector participated in this operation through an $\$ 85$ million loan shared by three Palestinian banks and Wataniya Mobile. This shows that the financial sector has begun to join the circle of investors and to look for new opportunities. We have many resources but limited investment channels.

This strategic partnership demonstrates that Palestine's telecommunications sector has significant growth potential and is capable of attracting regional and international investment. As cell phone usage in Palestine does not exceed $50 \%$ of the total population, which is comparatively low penetration, there are considerable opportunities for further investment. Wataniya mobile also presents opportunities though which the Palestinian economy can reduce its dependence on the Israeli economy

The development of Wataniya Mobile will benefit the Palestinian economy by creating hundreds of new job opportunities. Infusing competition into the currently monopolized telecommunications sector. In addition, Wataniya Mobile will also create hundreds of business opportunities for small-and-medium-size enterprises (SMEs) in complimentary sectors given that telecom companies will need to employ engineers, technicians, electricians, distributors, advertising companies, and other servicing companies.

The Gaza Gas Project is one where PIF is a partner in the international consortium with British Gas (BG) and Consolidated Contactors Company (CCC) that holds the concession to develop and exploit the Palestinian gas field off shore Gaza. Natural gas is one of the most important Palestinian natural resources. Its successful extraction and marketing is expected to infuse much needed into the Palestinian economy and invigorate it.

PIF has thus dedicated special attention in 2007 to the development of the gas reserves located in the Gaza Strip's regional waters, in partnership with British Gas (BG) and the Consolidated Contractors Company (CCC), by safeguarding this key Palestinian natural Resource and affirming the centrality of Palestinian rights and preserving Palestinian interests in the project.

In 1999, the Palestinian National Authority (PNA) granted a consortium comprised of PIF, BG Group and the Consolidated Contractors Company (CCC), the right to explore for and develop natural gas offshore the Gaza Strip. The following year, the group discovered approximately 30 billion cubic meters of natural gas in two fields, Gaza Marine and Border Field which are expected to be worth billions of dollars. The total amount of exploration and development costs are projected to reach $\$ 700$ million spread over three years

The successful implementation of the project will reflect positively on the economy as a whole and will enhance confidence in the overall investment environment in Palestine. Replacing diesel with natural gas as the fuel of choice by the Palestine Electric Company in Gaza will greatly reduce the cost of generating electricity, thereby driving prices down and benefiting consumers and businesses. Gas also produces less pollutants and is far more environmentally friendly; its promotion is thus in line with PIF's commitments to a clean environment in Palestine.

Gaza Gas is a strategic asset to Palestine due to huge revenues for the Palestinian Economy, which will be generated to the Palestinian Authority in the form of taxes and royalties. As exhibited in the chart below, the Palestinian side in this project is expected to earn roughly 50 percent of its profits, which includes the PNA's 
intake and PIF's profits. The PNA's government intake from the Gaza Gas Project is considered relatively high in comparison to similar developments in other countries, and is projected to reach more than 40 percent of profits. On the other hand, Billion Dollar Savings in Electricity Costs will be resulted. For instance, by replacing the diesel fuel used by the Gaza Power Plant with natural gas, the cost to produce electricity will be reduced by more than $\$ 1$ billion over the life of the project. Another benefit is reduced reliance on Israeli diesel fuel, which will contribute to bolstering Palestine's economic independence. Additionally, if the project's partners decide to export the gas to Israel, it will create a better trade balance between the PNA and Israel. Development in the Face of Adversity PIF and its partners (the Developers) have faced several obstacles that have prevented them from successfully exporting and marketing Palestine's natural gas. The Developers have yet to reach a deal with Israeli authorities to export the gas to Israel via a pipeline.

The chart below demonstrates that Gaza Marine provides a high percentage of revenues in comparison to what other countries intake from similar developments. Therefore, Palestinian authority gains a high comparative advantage in relation to those countries.

2. To what extent do the Investment Programs for the Industrial and Trading Sector comply with the determinants of national competitive advantage specifically?

\subsection{Factor Condition:}

The basic conditions are intact like labor and capital. The inputs in this sector is very promising and if explored can translate into important productivity.

\subsection{Demand Condition:}

This sector advanced demand. They catered to both domestic and international market. The political and legal constraints are in place which impedes the movement of goods from domestic to international.

\subsection{Supporting and Related Industries:}

The support of Gaza Juice to the agriculture sector is high as it provides the company the basic inputs.

\subsection{Firm Strategy, Structure and Rivalry:}

Before this can be realized, there is a need to address the legal and political constraints so that management strategies will be better.

\section{Conclusion}

In the year 2008, Wataniya Mobile announced that it had secured an unprecedented $\$ 85$ million syndicated loan from group of foreign and local banks and international organizations to build the next stage of its network.

The success of Wataniya Mobile in attracting such funding is evidence of the international banks and financing institutions' confidence in the company's potential performance and in Palestine as a whole, as well as the ability of local creditors to fund large-scale project. The syndicate that was formed in order to provide the $\$ 85$ million loan is comprised of the Bank of Palestine, Al-Quds Bank and the Commercial Bank of Palestine - all of which are based in Palestine. The foreign members of the syndicate are Ericsson Credit AB, the International Finance Corporation (IFC) and Standard Bank, which serve as the syndication's common agent.

The Palestinian telecommunications sector has grown rapidly in recent years as demand for Internet access, fixed phone lines and cell phone technology has spiraled. According to the Palestinian Central Bureau of statistics (PCBs) in 2004, 40.8\% of Palestinian households had a fixed phone line compared with $47.5 \%$ in 2009.

Nonetheless penetration remains comparatively low, with significant catch-up pot. The consistent growth in Palestine's telecommunications sector makes the market exceptionally attractive, especially in context of the current dynamism in information technology. Fixed and cellular phone penetration in Palestine is relatively low comparison to regional and international usage, thus growth opportunities remain significant. The 
telecommunications sector remains one of Palestine's most promising sectors with further growth and Development Expected.

\section{References}

Greenaway, D. (1993). 'The Competitive Advantage Of Nations, By Porter, Michael E.' Kyklos, 46, 1, $145-146$.

Grant. R. M., 1991.Porters Competitive Advantage Of Nations: An Assessment. Strategic Management Journal, Vol.12, 535-548

Porter M. E. (1990). The Competitive Advantage Of Nations, Macmillan, London

Porter, M. E. (1995). 'The Competitive Advantage of the Inner City', Harvard Business Review, May-June, 55-71.

Porter, M. E. and the Monitor Company (1991). Canada at the Crossroads, Business Council on National Issues and Minister of Supply and Services, Ottawa

Pressman, Steven (1991), 'The Competitive Advantage of Nations, by M. E. Porter, Journal of Management, 17, 1, 213-227.

Porter, M. E. and Christian, H.M., 2003. UK Competitiveness: moving to the next stage

Porter, M. E., 2009. The Competitive Advantage of Nations, States and Regions

Swift. T and zadek.S, 2002.Corporate responsibility and competitive advantage of nations

Smit. A.J., 2010.The competitive advantage if nations. Is Porter's diamond framework that explains international competitiveness of countries?

Aiginger, K. 2006. 'Competitiveness: from a dangerous obsession to welfare creating ability with positive externalities', Journal of Industrial Trade and Competition, 6: 63-66.

Balassa, B.A. 1965.Trade liberalization and revealed comparative advantage. Manchester School, Working Paper No. 33. May.

Baldwin, R.E. 1971. 'Determinants of commodity structure of US trade', American Review, 61(1): 126-146. The competitive advantage of nations 125

Baldwin, R.E. 1979. 'Determinants of trade and foreign direct investment: further evidence', Review of Economics and Statistics, 61(1): 40-80.

Barney, J.B. 1994. 'Strategic factor markets: expectations, luck, and business strategy'

Rumelt, R.P., Schendel, D. \&Teece, D. (eds), Fundamental Issues in Strategy: a Research Agenda. Boston, MA: Harvard Business School Press.

Barney, J.B. 2002. 'Strategic management: from informed conversation to academic discipline', Academy of Management Executive, 16(2): 53-57.

Bellak, C.J. \& Weiss, A. 1993. 'A note on the Austrian “diamond”, Management International Review, 33(2): 109.

Bernhofen, D.M. \& Brown, J.C. 2004. 'A direct test of the theory of comparative advantage: the case of Japan', Journal of Political Economy, 112(1): 48-67.

\section{Copyrights}

Copyright for this article is retained by the author(s), with first publication rights granted to the journal.

This is an open-access article distributed under the terms and conditions of the Creative Commons Attribution license (http://creativecommons.org/licenses/by/4.0/). 